spirits, and tobacco. For instance, beer-duty is charged according to the specific gravity of the brewer's wort before fermentation, and this gravity is " declared" by the brewer himself. To test the accuracy of such declarations, 6370 samples of wort in various stages of fermentation were analysed, with the result that the amount of duty was increased in more than to per cent. of the cases. Again, on beer which is exported, "drawback" corresponding to the original duty can be claimed: to check the claims, samples of the beer are analysed; and during the year 2789 barrels were found to be not entitled to the drawback claimed. $81_{3}$ samples of beer out of $65^{89}$ taken from publicans were shown by analysis to have been illegally diluted with water. Of socalled " temperance" "drinks, about one-third of the whole number examined, ror1, contained alcohol in excess of the legal limit, the highest quantity being about as much as in ordinary light beer. Fortymfour specimens of beer and brewing materials were found to contain arsenic in objectionable amount.

As regards spirits, it is noted that the exportation of medicinal tinctures, flavouring essences, and perfumes is increasing. So, too, is the use of denatured alcohol for industrial purposes, and of pure duty-free spirit issued to medical and other science schools.

Tobacco is examined chiefly to prevent an excessive admixture of water or oil; penalties were imposed in 87 cases of this kind during the past year, and also in other instances where glycerin and liquorice were unlawfully present.

Legal proceedings are necessarily a feature of the chemical control over dutiable articles. Penalties aggregating $5072 l$. were imposed during the year in respect of offences proof of which depended upon the analytical evidence.

Much work, of very varied scope, is carried out for the Admiralty, the Boards of Trade and Agriculture, India Office, Post Office, War Office, and other State departments. Imported dairy produce, for instance, is analysed for the Board of Agriculture in order to check the importation of adulterated foodstuffs; 2468 such articles were examined in the year, of which 2 IIO were butter and 305 milk and cream. Boron preservatives and artificial colouring-matter are found to be common additions to the butter. The use of the preservative is increasing; but, as the principal chemist points out, there is a difficulty in restricting the admixture so long as a legal limit has not been fixed. In two other respects it would seem that the law might well be amended. Butter, about the purity of which there were grave doubts, and cheese containing merely nominal amounts of fat, had, "in the absence of legal limits," to be admitted into the country without objection; this seems hardly fair, either to the home farmer or to the consumer.

In connection with the testing of filters, a useful note of warning is given to the makers of these articles. The actual filtering material may be quite satisfactory, but as regards giving a sterile filtrate the whole apparatus is sometimes rendered useless by leakage of unfiltered water through faulty fittings.

For the Home Office an interesting series of leadglaze samples was examined during the year. It may be remembered that cases of lead poisoning in the pottery industry had a few years ago become so numerous as almost to constitute a public scandal. Profs. Thorpe and Oliver, who were commissioned by the Home Secretary to investigate the matter, recommended, among other remedial measures, the substitution of lead silicates for the white lead then in general use as a glazing substance, on the ground that the silicate, properly compounded, would be almost insoluble in the acids of the gastric iuice, and therefore far less poisonous than the easily soluble whitc lead. Based on this recommendation, a regulation was framed by the Home Office; it was, however, thought by the potters to be too stringent, and eventually the point was submitted to arbitration, Lord James of Hereford being umpire. His award was in the nature of a compromise giving the manufacturers greater freedom than under the original proposal. The conditions are set forth in the report, together with the results of the analyses of samples of glaze showing how nearly the manufacturers, in the first year's working of the new rules, have been able to keep their glazes within the specified limits. On the whole, the results are fairly satisfactory. Thus thirty samples were represented as "leadless," and all but four did, in fact, conform to the regulation.

The India Office requires the analysis of a great variety of articles, which are examined in order to ensure that goods supplied by contractors are actually what they purport to be. Metals and alloys, cements, chemicals, disinfectants, drugs, food preparations, oils, paints, and surgical dressings were among the supplies sent for analysis during the year; but how far they proved to be satisfactory is not stated.

In cases which arise under the Sale of Food and Drugs Acts there may be a conflict of testimony, and the magistrate may wish to have before him independent evidence upon the chemical aspects of the question. In such matters the Government Laboratory acts as amicus curiae, and examines a sample of the article in dispute which has been specially reserved for that purpose. Further, whether the magistrate wants it or not, either of the litigants can claim to have this reserved sample forwarded for analysis. This is an excellent provision, securing as it does a careful examination of the disputed points by chemists unconnected with either prosecution or defence, and detached from any local influences which might, however wrongly, have been alleged or suspected by an accused person to have been used against him. During the past year this provision has been taken advantage of in rog instances. The net result of the references was to support the allegation brought against the article in the great majority of cases, viz. in 95 out of 105 .

The report bristles with matters of interest similar to the foregoing. It is the record of a useful year's work.

\section{ON THE ORIGIN OF EOLITHS.}

THE more detailed paper by M. Marcellin Boule on the subject of the origin of eoliths (see Niture, August 3I, p. 438) has now appeared in l'Anthropologie (Tome xvi., p. 257), and was briefly noticed in NATURE of September 28 (p. 538). The paper is too long for us, with the existing pressure upon our space, to give a full translation of it, but the following are the principal new features in the extended essay. The velocity of the circumference of the wheels in the délayeurs, or vats, is stated to be about I $_{3}$ feet per second, the same as the speed of the Rhone in times of flood. It will therefore be seen that these mixing vats are of an entirely different character from ordinary pug-mills, and that the motion of the water in them may be properly described as torrential. The author attaches no importance to the fact that some of the blows to the flints are given by the iron teeth of the suspended harrows, and states that most of the flints are reduced to the condition of rolled pebbles, identical with those to be found in all flint gravels, but that there are numerous examples of retouches, or secondary working. In illustration of this he gives photographic figures of eleven different specimens by which he contends that 
the analogy of these flints from the cement manufactory near Mantes with the so-called eoliths from Tertiary beds is substantiated, and he regards it as undeniable that these Mantes eoliths have been produced, and are being continually produced, apart from the intention of any human being.

In conclusion, he directs attention to the importance of migration both in history and in the development of all fossil groups. Nothing, he says, proves that the evolution of the human species or genus took place in one particular spot. It is very possible that man appeared suddenly in this part of the world at the beginning of the Quaternary period, at the same time as the mammalian fauna of which he forms part, and which is very different from the last fauna of Pliocene times. As a palæontologist, he believes firmly in the existence of Tertiary man, traces of whom, he doubts not, will eventually be found in some part of the world; but for these to be indisputable, they must possess a very different value from that of the eoliths.

In addition to M. Boule's memoir, an important article has appeared in the Archiv für Anthropologie (Neue Folge, vol. iv., p. 75), "Zur Eolithenfrage." It is from the pen of Dr. Hugo Obermaier, of Paris, who has also visited the cement works near Mantes, and entertains views upon the subject almost identical with those of M. Boule. He begins with a historical sketch of the discoveries of eoliths in beds from the Oligocene downwards to the Quaternary, and then proceeds to describe and discuss the modern products of the delayeurs, of one of which he gives a section. The paper is illustrated by eight plates, six of which are photographic. The first gives eight specimens of reputed eoliths from Miocene beds at Duan, near Brou (Eure et Loire). The other five are devoted to examples from Mantes, not a few of which present the "hollow-scraper" notches so often seen on eoliths. The remaining two plates contain reproductions of wood-cut figures of eoliths from various localities, so as to afford means of comparison between the old and the new.

He directs attention to an admission of M. Rutot that the eolithic industry is confined to localities where two conditions exist, the one that there was an abundance of the raw material flint, and the other that there was a stream of water in the neighbourhood, conditions which, in a modified form, exist at Mantes.

Want of space precludes a longer notice of this interesting article. We may, however, quote Dr. Obermaier's words in a letter to the editor of the Archiv für Anthropologie (Neue Folge Corr. Blatt., July, I905, p. 50):- "We have now an experimental proof that eoliths can be formed in a purely mechanical manner.'

\section{NOTES.}

As already announced, the inaugural meeting of the British Science Guild will be held on Monday next, October 30 , at the Mansion House, at 4.15 p.m. The Lord Mayor will preside, and will be supported, among others, by the Lord Bishop of Ripon, Lord Strathcona and Mount Royal, the Right Hon. R. B. Haldane, K.C., M.P., Admiral Sir Cyprian Bridge, G.C.B., General Sir Frederick Maurice, K.C.B., Sir John Wolfe-Barry, K.C.B., F.R.S., Sir William Ramsay, K.C.B., F.R.S., Mr. C. W. Macara, and Sir Norman Lockyer, K.C.B., F.R.S.

A menting of the general committee of the British Association will be held in the rooms of the Linnean Society, Burlington House, on Tuesday next, October $3 \mathrm{I}$, No. 1878 , vOL. 72$]$ at 3 p.m., for the purpose of appointing officers for the meeting of the association to be held at York next year, and of deciding upon the place of meeting in 1907 .

The Paris correspondent of the Times states that M. Gérault-Richard proposes to ask the French Parliament to vote a credit of 100,000 francs $(4000 l$.) for the investigation of the best means of combating tuberculosis. The Minister of Education, M. Bienvenu-Martin, has promised the support of the Government.

THE death is announced of Prof. DeWitt Bristol Brace, head of the department of physics in the University of Nebraska, and one of the leading physicists of the United States. He was in his forty-seventh year, and had just entered upon his nineteenth year of teaching in the University of Nebraska.

AN international exhibition in connection with ceramic industries, and with the manufacture of glass and crystal, will be held in 1906 from June to October at the ChampsElysées and the Cours-la-Reine. Full information can be obtained from the director-general of the exhibition, I9 rue Saint-Roch, Paris.

WE learn from the Pharmaceutical Journal that the Heriot trust governors have decided to establish a laboratory at the Heriot Watt College, Edinburgh, for the study of bacteriology in its relation to various industries. The laboratory has been fitted with the best ap':ainces, and the services of Dr. Westergaard have been retained to supervise it. The laboratory was formally opened by a lecture by Prof. Hansen on October 18 .

A strong earthquake shock was felt in Constantinople on October 22 at 5.55 a.m. The disturbances, which lasted several seconds, appeared to travel from the north-east towards the south-west, and were accompanied by a rumbling noise. Earthquake shocks were felt at 2 p.m. on the same day at Batum, and between 2 p.m. and 5 p.m. at Kutais. An undulating tremor lasting forty seconds was also experienced at Sukhum-Kaleh.

A CONFEREnce of delegates from the corresponding societies affiliated to the British Association will be held in the rooms of the Linnean Society on Monday and Tuesday, October 30 and $3 x$, under the presidency of Dr. A. Smith Woodward, F.R.S. Among the subjects to be discussed are "The Preservation of Native Plants," to be introduced by Prof. G. S. Boulger, and "The Law of Treasure Trove," which will be introduced by Dr. W. Martin. The delegates will visit the museum of the Royal College of Surgeons, and will dine on Monday evening as guests of the Royal Societies Club.

A Reuter message states that the Berlin Meteorological Observatory, which the Emperor recently opened in the presence of the Prince of Monaco, is fitted with all the latest appliances for meteorological research. The Emperor attaches great importance to the use of balloons in meteorology, so that an extensive balloon hall has been included in the building plan of the new observatory at Lindenberg, near Berlin. On the highest point of the plateau on which the observatory stands is a shed which can be turned to any point of the compass, and contains a cable drum driven by a small electric motor for hauling in kites, which are to be extensively used for meteorological purposes. Electric search-lights have also been installed for night observation. Another interesting feature of the new institute is the kite factory, where large kites, fitted with self-registering instruments, are made. The institute has its own establishment 